Ta'dib: Journal of Islamic Education

Volume 21, Number 2, December 2016

\title{
Dialectics of Educational Technology and Reposition of Islamic Religious Education: Teachers' Role in Globalization Era
}

\author{
Agus Purwowidodo \\ Institut Agama Islam Negeri Tulungagung, Indonesia \\ E-mail:aurorasekar@yahoo.com
}

Received: $28^{\text {th }}$ September $2016 \quad$ Revised: $19^{\text {th }}$ October $2016 \quad$ Accepted: $27^{\text {th }}$ November2016

\begin{abstract}
Learning technology as applied disciplines grows and evolves based to the needs of learning more effective, more efficient, more and more, more spacious, and more quickly in the globalization era. And also solves the problem, facilitating problem solving learning on design aspects, development, utilization, management, and assessment processes and sources in learning. Islamic religious education teachers challenge in the global era is the demands of the learning process that can improve informationliteracy that is well supported by data and facts to deliver to the students in the era of information society (information society) and the scientific community (knowledge society). So it is needed an approach and innovative methods of learning strategies that address the challenges of learning needs in the era of globalization and information. Dialectics of technology on learning in a globalization era are characterized by the demands of the students to have critical thinking skills, problem solving, innovative and creative, mastering ICT, fluent communication, and multi languages. And also Islamic religious education teachers' competence and interaction and learning technologies such as ICT products that push reposition the role of an advanced teacher trainers, counselors, managers, participants, leader and author of learning works as an abstraction and a high commitment as a base quality of professionalism.
\end{abstract}

Keywords: Technology, Learning, Teachers, Globalization

\begin{abstract}
Abstrak
Teknologi pembelajaran sebagai disiplin ilmu terapan tumbuh dan berkembang sesuai kebutuhan belajar lebih efektif, lebih efisien, lebih banyak, lebih luas, lebih cepat di era global. serta memecahkan, memfasilitasi pemecahan masalah belajar pada aspek desain, pengembangan, pemanfaatan, pengelolaan, dan penilaian prosesproses dan sumber-sumber untu belajar. Tantangan guru PAI di era global adalah tuntutan terhadap proses pembelajaran yang mampu meningkatkan information literacy yang baik didukung oleh data dan fakta untuk menghantarkan siswanya menuju pada era masyarakat informasi (information society) dan masyarakat ilmu pengetahuan (knowledge society). Sehingga di butuhkan bentuk pendekatan strategi dan metode inovatif pembelajaran yang mampu menjawab tantangan kebutuhan pembelajaran pada era globalisasi dan informasi. Dialektika teknologi terhadap proses pembelajaran di era global diwarnai dengan tuntutan terhadap siswa mempunyai keterampilan dalam berpikir kritis, memecahkan masalah, inovatif dan kreatif, menguasai ICT, komunikasi lancar, multi bahasa. Serta interaksi kompetensi Guru PAI dan produk teknologi pembelajaran berupa ICT yang mendorong reposisi peran guru menajdi pelatih, konselor, manajer, partisipan, pemimpin serta pengarang karya pembelajaran sebagai daya abstraksi dan komitmen yang tinggi sebagai basis kualitas profesionalisme.
\end{abstract}

Kata Kunci: Teknologi, Pembelajaran, Guru, Globalisasi

\section{Introduction}

Technology is an integral part of each culture to a more advanced culture, more and more sophisticated technologies used in the world of education, the role and position of learning technologies are also an integral part of education. In Fact, there are many people who do not admit even the existence honing learning technology to help in solving the problems of education in general and teaching in particular. For those technologists both practitioners and academics of learning have to think and act proactively to address 
these challenges, to prove and develop learning technologies so that benefits are extensive, especially in facing of the globalization era.

Learning technology is the practical application of knowledge to work on something that we want in the world of learning. In the process, the learning experience challenges in the era of globalization. Therefore, it should have the prospect of learning technology which is used or is associated with innovative and integrative learning process of the application of ICT to achieve the goal of effective learning.

The goals of learning technology such as: (1) Learning technology is able to solve the problem and or facilitate in problem-solving to lifelong learning in humans, anywhere, everywhere, in any way, and by anyone; (2) as well as process improvement and also tool that enables a generation which uses knowledge of the previous generation (Reiser, 2002: 1995). (3) According to AECT (Association for Educational and Technology) said that the prospect of rather than learning technology that includes two fundamental, they are (http://www.aect.org): (a) to analyze the problem of finding, implement, evaluate, and manage solving problems related to all aspects of human learning and (b) to help to bridge and overcome learning problems.

Learning technology is an applied discipline, it means that it develops based on needed in that field, namely the need to study (learn more effectively, more efficiently, more and more, wider, faster, and so on). For the reason there is a product that is deliberately created, found, and be used. But the development of Information and Communication Technology (ICT) that is unbelievably fast lately and offers a number of possibilities previously unimaginable had reversed our thinking with "how to take advantages of these technologies to address the problem of learning".

The prospect of the learning technology is trying to solve and or facilitating in problem-solving of lifelong learning in human anywhere at any time in any way and by anyone. According to Burton, John and Barbara Locke (2000) that the prospect from learning technology is a process improvement as well as the means by which a generation which uses knowledge of previous generations. This reality illustrates that the learning process is badly affect the quality of education that have implications for the low quality of Indonesian human resource development.

Seeing the strategic role of the teacher in this learning process, especially in the globalization era, the availability of teachers who have quality and comprehensive competence in the aspects of pedagogical, professional, social, and personal competence becomes a necessity to improve the human development index in Indonesia in the era of the Association of South East Asian Nation (ASEAN) Economic Community (AEC). This positive response should be indicated by constantly doing improvement of the quality of teacher education programs that impacts in developing qualified teachers.

On the other hand, obstacles and challenges in the perspective of qualified and competent teachersobal competitiveness are not easy. Because it takes the optimization of the components that contribute to the quality of the learning process and results, according 
Dialectics of Educational Technology and Reposition

of Islamic Religious Education: Teachers' Role in Globalization Era

Agus Purwowidodo

to Earle, R.S., Persichitte, K. A (2005: 102) consisted of students, teachers, materials, methods, learning resources, infrastructure and cost. In this component, teacher play a very important in improving the quality of the learning process and results. This is supported by the opinion fromYusuf Hadi Miarso (2005: 57) that said that teachers as teaching agent demanded to organize the learning process is well within the framework of national development which refers to the five things, namely suitability, attractiveness, effectiveness, efficiency, and productivity in the learning process (Miarso, 2008).

Implementation of quality learning process in order to improve quality education should be based on Law No. 14 of 2005 which states that teachers are professional educators with the primary task of educating, teaching, guiding, directing, train, assess, and evaluate students ... as well Government Regulation No. 19 of 2005 on national education standards that states that teachers must be competent in performing the tasks their profession and be able to apply appropriate educational technology. How dialectic application of learning technologies to reposition the role of the teacher in the learning process in the global era can be seen as an innovative strategy that is done by teachers in improving the quality of learning will be studied in this paper.

\section{Research Findings and Discussion}

\section{Perspective of Educational Technology in Facing Globalization Era}

The concept of learning technology as applied science disciplines, develops due to the demands and needs for creating, designing learning activities more effective, efficient, more and more, more quickly and with quality. This is in accordance with the opinion of Seels and Richey were told that learning technology is the theory and practicing in design, development, utilization, management, and assessment processes and sources for learning (Miarso, 1987: 90). Meanwhile, according to AECT 1994 formulation of the definition of learning technologies are:

Instructional technology is a complex, integrated process involving people, procedures, ideas, devices, and organization, for analyzing problems, and devising, implementing, evaluating and managingsolutions to Reviews those problems, in the situation in which learning is purposive and controlled (Heinich, 1996: 71).

Is analyzing in deeply, according to AECT in 1994, learning technology can be defined: (1) the theory and practice; (2) the design, development, utilization, management, and evaluation; (3) processes and resources; and (4) learning. The primary mission is to assist the learning technology, and stimulate the learning process, and provide learning facility. The achievement of learning goals in the form of changes in knowledge, skills, and attitudes are relatively fixed posed by the experience, not because maturity is the main criteria of learning.

Januszewski and Molenda (2001: 113) also believe that learning technology is the study and ethical practice of facilitating learning and improving performance by creating, using and managing the processes, and sources of appropriate technologies. From the previous opinions, it can be concluded that the mission of learning technology is concerned to facilitate, improve performance, simplify, and solve the problem of students learning 
(learner) to create better, faster, fun, and effective teaching and learning process. It is also supported by a good management, learning resources, and appropriate learning system.

The challenge of learning technology in the future is how teachers are able to design and create innovative learning environments. An innovative environment is as defined by the SETDA to the learning environment and the class model in 2020 are: (1) provided a learning environment that supported high technology and speed of access, (2) selflearning, (3) online and Blended Learning, (3) digital and open content, (4) project-based collaborative learning (http://www.setda.org/web/guest/nationaltrend).

It is also supproted by Evans, Lionel, and John Leedham (1985: 61) opinions. They state that constraints the use of learning technology in the era of globalization are: (a) the limitations of human skill in mastering the learning technologies; (B) the cost or efficiency constraints; (C) the progress of learning technologies coupled with moral decadence; (D) the lack of dissemination of learning technology in educational institutions; (E) the challenge of psychology is the psychological condition of a person can hamper communication processes both in terms of enthusiasm, communication, self-confidence, and comprehension; (F) cultural challenges, namely the local culture are often different from other regions. If in the process of communication lack of understanding, it will cause delays in communication; and ( $\mathrm{g}$ ) environmental challenges, namely a conducive environment has an important role in the learning process so that the process of learning communication can run well.

Therefore it is necessary to do a comprehensive study based on the ethics of the profession to facilitate learning and improve the performance of teachers through the creation, use, management of appropriate technology to process and learning sources. By the rapid development of technology, it makes demands on teachers are increasingly complex given the number of variables which should be addressed in teacher quality learning process, involving the school administration and management skills of students.

According to Gagne (1991: 172) teacher who has a good competence is appropriate to be a: (a) the designer of instruction who creates teaching and learning activities, the draft pick and choose at least includes Creating learning materials, formulating learning goals, selecting appropriate learning methods and implementing the evaluation activities in learning; (b) the manager of instruction that is able to manage learning situations and learning conditions of effective and democratic; (c) theevaluator of studentlearning who always follows the development stage of the progress of student achievement in every period of learning.

According to Januszewksi, A., and Molendaare (20808: 70), Essential Skills that are dominated by teachers in the future such: (a) the digital age literacy; (b) inventive thinking; (c) effective communication; (d) and high productivity. Teachers who want to be succeed in the future are advised to master digital technology. The smart teachers will be able to think critically to solve problems as well as creative and innovative in their work. If competence is accompanied by the ability to communicate effectively and able to cooperate with other people, then challenge any heavy impassable by the teachers. 
Dialectics of Educational Technology and Reposition

of Islamic Religious Education: Teachers' Role in Globalization Era

Agus Purwowidodo

According to Hartoyo (2008) professionals teacher are teachers that always changesold practices, even willing and able to leave the methods and recipes for success in the past.This is done by a teacher in order to face the challenges in the present and future, through learning and innovate continuously, critical thinking in problem solving, creative and innovative in their work, be able to communicate effectively and mastered digital technology and to master in ICT.

Prospects learning technology in era of globalization could encourage teachers to create a knowledge society, the society that believes that knowledge and human skills are far more important than natural resources, abundant material and facilities modal. By existing media, learning technology can be optimized and a solution in resolving the problems in the world of learning through space and time in communication, providing knowledge of science in teaching, make it easier to obtain information from the outside that the data assist students in dealing with problems and also develops learning process and results in accordance with level developing critical thinking of students.

Related to that, teachers as educators should be able to professionally in answering these challenges. According to Zainal Aqib (2009: 19), there are four sizes of a teacher professional They are as follow: (a) having a commitment to students and the learning process; (b) in-depth control of teaching materials and how to teach it; (c) having responsibility in monitoring the learning ability of students through a variety of evaluation techniques; (d) he should be part of a learning community within their profession. To apply the optimal learning process, teachers have a strategic position.

On a strategic and fundamental role of teachers in planning, implementing and evaluating teaching and learning activities, education experts Marsh, C.J (1996: 106) stated: "I've never seen a good student without a good teacher". This simple sentence implies the real depth meaning, because honestly it must be recognized no matter how nice and neat system and learning program designed, but it will determine the outcome, in terms of the achievement of the desired quality is determined by the administrators (teachers). For the implementation of teaching activities in the classroom, the teacher holds a very strategic role, both in his capacity as a teaching planner, executor of teaching, until the process of assessing student learning outcomes. Even further, through feedback obtained during the process as well as feedback obtained through the recording of learning outcomes that are picked through an adequate evaluation process, teachers are also expected to be able to modify the design and implementation of the teaching.

Prospects learning technology in era of globalization according to Suyanto (1997: 47) are: (1) learning technology capable of creating Knowledge Society that is people who believe that knowledge and human skills are far more important than natural resources, abundant material, and capital; (2) With the facility of learning media (instructional technology), should be able to run optimally; (3) learning technology is a policy to resolve the problems in the world of learning; (4) learning technology is able to penetrate the distance of time and space in the world of communication in education; (5) learning technology can feature various types of audio-visual materials including still images, movies, objects, specimen; (6) learning technology give new knowledge about science in 
teaching; (7) learning technology makes easy to obtain information from the outside that can help us in dealing with problems; (8) learning technology can enhances the learning process and results with respect to the level of thought students (Margot, 1999).

While the learning technological challenges of globalization era are: (1) the limitations of human skill in mastering the learning technologies; (2) problems with the cost or efficiency; (3) advancement of learning technologies coupled with moral decadence; (4) lack of socialization of learning technologies in educational institutions; (5) The psychological challenges that can hinder a person's psychological state communication process both in terms of enthusiasm, communication, self-confidence, and comprehension; (6) cultural challenge is the culture of a region is often different from other regions. If in the process of communication lack of understanding, it will cause delays in communication; (7) the environmental challenges is a conducive environment has an important role in the learning process so that the process of learning communication can work well.

The challenge of learning technology itself include: (1) the increasingly rapid social changes have implications for the shift in society's values; (2) The absence of new innovations related to the kinds of learning technology in terms of both technology and process and systems; (3) In connection with the use of technology, lack of teachers' mastery of the technology raises concerns about students, so it does not have a close relationship with the teacher students become passive implications for the use of technology; (4) The existence of a global transformation is not always a positive thing. The number of entertainment out of control, the amount of grain that is less educated, the violence there and thus may cause more students imitate and do what is heard and seen through technology causing things that are not desirable.

Learning technology will experience developing in line with there is a product that deliberately and there are discovered and exploited. But the development of information and communication technology very rapidly lately and offers a number of possibilities previously unimaginable had reversed our thinking with "how to take advantage of these technologies to address the problem of learning?"

\section{Competence Islamic ReligiousEducation Teachers}

The emphasis of the education development is improving the quality of all levels and types of education is strongly influenced by the ability or competence of teachers. According to education experts Mangal and Mangal (2009: 113), the notion of competence is defined as the capacity to do something which is derived from the learning process. This is supported by the opinion of Yusuf Hadi Miarso (2004: 76) who said that the competence is a unified whole that illustrates the potential, knowledge, skills, and attitudes are considered related to certain professions with respect to the parts that can be actualized and realized in the form of action or performance for practicing a particular profession.

The Competence Problems of Islamic religious education teachers are between reality and idealism as social accountability can be seen through portraits Islamic religious education teachers who are teaching in schools, namely: 
Dialectics of Educational Technology and Reposition

of Islamic Religious Education: Teachers' Role in Globalization Era

Agus Purwowidodo

a. Picture shows that the knowledge of Islamic religious education teachers, though not all, have a lack of management of teaching and learning, knowledge evaluation and measurement, as well as knowledge of curriculum development. Disadvantages take serious attention, especially by governments, schools and as well as Islamic religious education teachers. If there is no improvement of the above shortcomings, the course goals Islamic religious education is not fully realized.

b. The teaching-learning process, Islamic religious education teachers are more concentrated in theoretical scientific issues that are purely cognitive and put more emphasis on teaching work / knowledge transfer.

c. Islamic religious education teaching methodology for this is generally not changed, he was like a conventionally-traditional and monotonous so boring the learners.

d. Islamic religious education teaching and learning activities are often concentrated in the classroom and are reluctant to do the practice and research activities outside the classroom.

e. The use of media for teaching at both the teachers and students are less creative, varied and fun.

f. Teaching and learning activities (KBM) from Islamic religious education tend to be normative, linear, with no illustrations socio-cultural context in which the environment of such learners are, or can be connected with the times that are rapidly changing.

g. Lack of communication and cooperation with parents in addressing the problems faced by learners (Sanjaya, 2010).

Islamic Religious Education (PAI) teachers as a professional educator and a learning agent should be able to organize the learning process with the best possible standard refers to the process of national education set out in the framework of national education. Therefore every teacher of Islamic religious education must master and understand and apply all of competences in supporting his duties as a professional educator. Referring to Law No.14 of 2015, the professional teachers will demonstrate the performance depicting the four competencies, namely pedagogy, professional, personal and social.

Among the four competencies, pedagogical and professional competence is the closest to actualized in learning performance. Pedagogical competence is closely related to the ability of teachers to understand the characteristics of students, the design and implementation of learning, implementing evaluation of learning outcomes and the ability of Islamic religious education teachers in developing students to actualize themselves. While the professional competence of Islamic religious education teachers actualized in the form of: (a) controlled substances is broad and deep and basic scientific methodology; (b) to master in the teaching materials in the curriculum; (c) are able to develop curriculum and learning in a creative and innovative; (d) to master the basics of matter extracurricular activities that support student achievement of learning goals; (e) be able to assess and improve learning through action research (Miarso, 2004: 90). Both pedagogical competence and professional qualifications must be improved and developed on an ongoing basis in line with the development of science, technology and art. 
The development of science and technology rapidly, has raised the complexity of the problems in the process of studying the Islamic religious education subject. These conditions require more specialist ability of Islamic religious education teachers in carrying out his duties in carrying out learning activities. So according to I Wayan Santyasa (http://www.freewebs.com/santyasa/pdf2/.pdf), a teacher must have a minimum of professionalism which involves three things: (a) skills (expertise) in accordance with the scientific field to be dominated to the area to be explored; (b) the commitment and responsibility; and (c) discipline in professional organizations (involvement in professional organization). In order to improve the competence of the teachers need a commitment that gave birth to his third collaboration to improve the quality of learning process and results.

The toughest challenge of Islamic Religious Education (PAI) teachers in globalization era claims against the learning process that can improve information literacy is well supported by data and facts to deliver to the students in the era of information society (information society) and the scientific community (knowledge society). So in need pronged approach strategies and teaching methods that address the challenges of learning needs in the era of globalization and information.

According to Sutrisno demands in response to globalization of learning has been present in sight, various computer devices and their connections in delivering students learn quickly and accurately when used correctly and appropriately, for it takes the teacher resources that are responsive to the utilization of process and product technology learning that ICT (Information and Communication Technology) (Gafur, 2010), and written by David Young (2013) that ICT-based learning has many advantages, such as the use of the time used to be more effective, materials subject matter becomes more accessible, attractive, and inexpensive cost.

In applying the concepts and principles of learning technology, to note the existence of problems, issues, or challenges to help the learning process of Islamic Religious Education optimally. The problems and challenges referred to broadly cover areas or regions of the different conditions and practices or implementation of education in educational institutions (Gairola, 2004: 27), by geography, demographics, economy, and culture of our country are various.

The presence of diverse utilization of process and product information and communications technology (Information and Communication Technology / ICT) can not be avoided in the process of learning activities can improve the quality of the learning process of Islamic Religious Education in digital era, according to the teachers of Islamic Religious Education is open, quick to adapt, independent, advanced, competitive and characterized by implementing and synergize the curriculum and the learning process of Islamic Religious Education is more efficient, innovative, effective, and optimal for the nation's progress (Gustafson, 1991, 52).

This is the challenge of learning Islamic Religious Education in the globalization era, the presence of learning technology requires students to be creative, innovative, critical thinking and metacognitive and they will be able to the students have the ability to 
Dialectics of Educational Technology and Reposition

of Islamic Religious Education: Teachers' Role in Globalization Era

Agus Purwowidodo

communicate and work collaboration (group) as well, then the knowledge and skills acquired can be the foundation live in a society that has character both locally and globally, and reliable personal and social. With the presence of learning technologies in the world of learning should be able to deliver the face of education towards a better and so challenge PAI learning in a global era can be resolved, of course inseparable from the role of teachers PAI as educators demanded creative and innovative develop learning by integrating technology and learning.

\section{Learning Model in the Era of Globalization}

Learning is a process of creating an environment that enables the process of learning. Learning in terms is the activity of students to interact with the environment that produces behavioral changes that are relatively constant (Burrow, 1993: 29).

The learning process in the global era characterized by the demands of the students who have skills in: (a) critical thinking; (b) able in solving the problem; (c) innovative and creative; (d) control of ICT; (e) communication smoothly; and (f) multi language (Suyanto, 1997: 82). Students are able to compete and prosperous in the new century and to be able to face more risks in the uncertainty lives and situations. Globalization passes a series of major changes in the world order as a whole. This era was marked by the process of life worldwide, the progress of science and technology, especially in the field of transformation and cross-cultural communication as well as the occurrence. The changes that are brought about by globalization are also experienced by the world of education with teachers as practitioners.

Along with the above characteristics in the globalization era, the Islamic Religious Education teachers must also face the challenges of a global society. In the global era, teachers are highly required to increase their professionalism as a teacher and educator. In addition to professionalism, teachers also have to face some key words, such as education, competition, transparency, efficiency, and high quality. From the social point of view, the global community will be very sensitive and concerned about the issues of democracy, human rights and environmental issues.

The challenge facing teachers of Islamic Religious Education in the global era such as the development of science and technology are so rapid and fundamental; moral crisis that swept the nation and country, social crisis and a crisis of identity as a nation. All of that obviously requires prospective teachers are professional and qualified. Teacher education programs should be able to provide excellent services to students so that they can print quality teachers. Improving the quality of education will foster public confidence so that still exist in the future.

As the implications of globalization and the reform, the change happens in the paradigm of learning. The change involves, first: the paradigm of learning-oriented process of teaching where the teacher is a resource center, shifted to the learning process oriented learning in which the student is the subject of learning (studentcenter). With so many alternative learning resources that can replace the function and role of the teacher, the teacher's role turned into a facilitator. Second, the paradigm of the traditional learning 
process oriented approach to classical and format in the classroom;it shifts to learning model that is more flexible, such as distance education system (e-learning). Third, the quality of learning is a priority, the growing popularity of lifelong education and further melting the boundaries between formal and non-formal education (Dantes, http://www.undiksha.ac.id/e-learning/staff/images/imginfo/4/7-7.pdf).

Learning paradigm that has lasted more focused now days more focus in teachers in the transfer of knowledge, art and culture to students are now experiencing a shift to position students as the main subject of study. In conclusion, now days behaviorist learning paradigm has shifted towards learning paradigm constructivist that give more roles to the students to construct the experience and develop the skill that are needed by themselves in accordance with their mindset.

Richard Labelle (2005: 77) said future society is the super-industrial society. To create these needs to be determined laden alternative assumptions about the type of job, profession takes between 20-50 years to come. From here will be formulated skills, cognitive, and affective that are needed to confront the changing acceleration.

The future is a complex period even the futurologist could no longer predict the future (Heinich, 1996: 63). Such being the case, the future of education should be able to educate people to be able to face future's complexity. The purpose of Islamic Religious Education is directed to create human who are able to follow future condition.

While the characteristics of learning must be designed by teachers in the perspective of learning technologies for the globalization era based on oponion of Nyberg, DA (1990: 47) are: (1) the process to have and allocate information, (2) the process to have a high level of skills to generalize, (3) the process of having a strategy common to solve the problem, (4) the process of defining their own learning objectives, (5) the evaluation process of own learning outcomes, (6) a strong motivation and (7) the process in having the right concept. Therefore, Islamic Religious Education teachers have a very vital role and fundamental in guiding, directing, and educates students in the learning process.

According to Ebiefung (2009), there are several globalization challenges that must be addressed by promoting teacher professionalism, they are as follow:

a. The development of science and technology are so rapid and fundamental. With this condition Islamic Religious Education teacher should be able to adjust to the responsive, wise and prudent. Responsive means that teachers must be mastered the science and technology products, especially those related to education.

b. The moral crisis that hit Indonesia. Due to the influence of science and technology and globalization has been a shift in the values that exist in people's lives.Through education, Islamic Religious Education teachers have their own challenges to instill moral values in the younger generation.

c. The social crisis, such as crime, violence, unemployment, and poverty in society. As a result of industrial development and capitalism, it appears the 
Dialectics of Educational Technology and Reposition

of Islamic Religious Education: Teachers' Role in Globalization Era

Agus Purwowidodo

social problems in society. They are weak in education, access and the economy will be the victim. It is a challenge Islamic Religious Education teacher to respond to this reality through education.

d. The crisis of identity as a nation and state of Indonesia. Globalization also has weakened national identity (nationalism) our youth. For that, the teacher of Islamic Religious Education as the guardian of values, including the value of nationalism should be able to provide awareness to students about the importance of nationalism in the life of the nation.

Responding to the issue, in improving the quality of learning, teachers must be able to develop three basic intelligences of students. Such as, intellectual, emotional and moral, those three elements must be inculcated in the students as strong as possible so imprinted in him. Another thing to note is the spiritual dimension of student teachers.

In conclusion, the teacher holds a strategic role in improving the quality of learning to master the four competencies, namely pedagogy, professional, personal and social competence to carry out duties as a professional educator. Besides competent, to improve the quality of learning should be supported by the application of learning technology in the form of collaboration between teachers and learning technology to design, develop, utilize, manage and evaluate the various media and learning resources in various forms of technology that can help meet the learning needs of students in accordance with level of cognitive development.

\section{Dialectics of Learning Technology, Islamic Religious Education Teacher Competence in the Globalization Era}

According to Hegel, dialectic method is a method or a way to understand and solve the problem or problems based on three elements, namely the thesis, antithesis and synthesis. Tesa is a question or a specific problem, while the antithesis is a reaction, a response, or comment critical of the tesa (argument from tesa). From those two elements are expected to emerge synthesis that is a conclusion. This method aims to develop a dynamic process of thinking and solving problems that arise because of their contradictory arguments or face so that a compromise was reached that rational (Ali, 2013).

The dialectical method is a method or a way to understand the dialogue. Which continuous and profound expectation of the people can solve the existing problems. There is the thought process of someone who is experiencing growth because it brings the idea with another idea that a dialogue between people. The goal is to develop a way to argue that the position of two-way and are expected to be known to each other.

The adult learning technology applications are such as process and product utilization of information and communication technology (Information and Communication Technology/ ICT). This technology is used to solve the problems of education and learning. Therefore, the learning technology has many benefits to help achieve the goals of education. In order learning technology can serve well in the world of education and learning, will need to establish appropriate strategies and optimal utilization to solve 
strategic problems ranging from learning among other things on the quality, relevance, efficiency, effectiveness, and competitiveness of human resources.

Growth and development of learning technology has contributed to the education, especially in the learning process. One form of learning technology products is rapidly growing Internet in the late $20^{\text {th }}$ century and on the threshold of the $21^{\text {st }}$ century presence has a considerable impact on learning in class in various aspects and dimensions. The Internet is one of the instruments in the era of globalization has made the world into a transparent and connected very easily and quickly without knowing the limits of territorial or nationality.

Through the internet every student can access to the global world to obtain information in various fields and at the turn will influence the direction of the overall student action. The existence of the Internet today is such a need modern learning issues in meeting the challenges of global development. This condition is certainly going to have an impact on the style and patterns of learning of students and teachers as a whole.

In this regard, every teacher who wants to survive and up to date in master and understand and then can apply their knowledge in the face of global challenges, need to upgrade their quality to adapt to the growing demands. Learning technology has changed the face of different learning with traditional learning process characterized by face-to-face interaction between teachers and students both in the classroom and outside the classroom.

In the era of globalization, the information flow will be increased through the Internet is global worldwide and requires teachers to adapt to the trend if not outdated. With this condition, then the teacher reposition in education, especially learning process sooner or later will reduce the role as the sole source of learning and is replaced by the existence of computers and the Internet as the main tool.

In learning activities students need guidance from teachers and parents in the process of learning with ICT support. In this regard, the teacher holds a very important role and should master the subtleties of ICT and, more important is the ability to facilitate the children's learning effectively. The teacher's role as a conduit of information should shift into the learning manager with a number of specific roles, because the teacher is not the only source of information, but only one source of information.

According to Rosenberg (2006: 42), the widespread use of ICT there are five (5) shifts in the learning process, namely: (1) from training to performance, (2) from the classroom to where and at any time, (3) of the paper to the "on line" or channel, (4) physical facilities to network facilities, (5) of the cycle time to real time. Communication as a medium of education is done by using communication media such as telephones, computers, internet, e-mail, and so forth. Interaction between teachers and students are not only done through face-to-face but also done using these media. Teachers can provide service without having to deal directly with students. Similarly, students can obtain information in a wide range of different sources through cyber space or virtual space using a computer or the internet. 
Dialectics of Educational Technology and Reposition

of Islamic Religious Education: Teachers' Role in Globalization Era

Agus Purwowidodo

The most recent is the development of so-called "cyber teaching" or virtual learning, the learning process is done by using the internet. Another term that is increasingly popular today is e-learning is a learning model by using the media and information communication technology, especially the Internet. According to Rosenberg (2006: 76), e-learning is the use of learning technologies in the form of internet in the delivery of learning in a broad range, which is based on three criteria, namely: (1) e-learning is the network with the ability to renew, store, distribute and share teaching materials or information, (2) delivery to end users via a computer using learning technology with the standard internet assisting, (3) focus on the most comprehensive view of learning beyond the traditional learning paradigm.

Currently e-learning has evolved in a variety of learning models based on ICT such as: CBT (Computer Based Training), CBI (Computer Based Instruction), Distance Learning, Distance Education, CLE (Cybernetic Learning Environment), Desktop Videoconferencing, ILS (Integrated Learning System), LCC (Learner-Centered Classroom), Teleconferencing, WBT (Web-Based Training). All based on the product application of learning technologies is the Internet.

Kenning, M.J. and M.M. Kenning (1984: 68) stated that in the future, the roles of teachers will be developed that teachers can as a coach (coaches), counselors, managers of learning, participants, leaders, learners, and the author as follows:

a. As a coach, teacher of Islamic Religious Education plays develop student learning according to their characteristics by providing principles and tips to learn effectively and efficiently.

b. As with counselors, teacherof Islamic Religious Education creates a learning interaction situation in the psychological atmosphere conducive and no distance is rigid with the teacher. In addition, teacher is expected to be able to understand the condition of each student and help him towards optimal development.

c. As with managers, teacher of Islamic Religious Education has the independence and autonomy of the widest in managing the overall learning activities by exploiting and using the entire software sources and learning supporting hardware in school.

d. As a participant, Islamic Religious Education teacher does not only behave teaching but also behaves learning from the interaction with the students. This implies that Islamic Religious Education teacher is not the only source of learning for the students, but he is as a facilitator of student learning.

e. As a leader, Islamic Religious Education teacher is expected to be able to become someone that can move the students to realize the behavior towards a common goal. Besides teaching, teacher should have the opportunity to manifest himself as a responsible party in various other activities out of teaching.

f. As an author, Islamic Religious Education teacher must always be creative and innovative to produce a variety of work that will be used to carry out professional duties. Teachers independent rather than as a plumber or technician must follow a standard guide, but as a creative force that is capable of producing 
a wide range of innovative work in the field. It should be backed by the power of abstraction and commitment as a basis the quality of professionalism.

Table 1: the Role Repositioning of Teachers in the Era of Globalization

\begin{tabular}{|c|c|c|}
\hline \multirow[b]{2}{*}{ Environment } & \multicolumn{2}{|c|}{ Model of Repositioning Learning } \\
\hline & Traditional & Era of Globalization \\
\hline Class activities & $\begin{array}{l}\text { Teachers as a central and } \\
\text { didactic }\end{array}$ & $\begin{array}{l}\text { Students as central and } \\
\text { interactive }\end{array}$ \\
\hline The role of teachers & $\begin{array}{l}\text { Delivering the facts, the } \\
\text { teacher as expert }\end{array}$ & $\begin{array}{l}\text { Collaborative, sometimes } \\
\text { students as experts }\end{array}$ \\
\hline $\begin{array}{l}\text { Given the emphasis } \\
\text { of teaching }\end{array}$ & Remembering the facts & $\begin{array}{l}\text { The relationship between } \\
\text { information and findings }\end{array}$ \\
\hline $\begin{array}{l}\text { The concept of } \\
\text { knowledge }\end{array}$ & $\begin{array}{l}\text { Accumulation of facts in } \\
\text { quantity }\end{array}$ & Facts transformation \\
\hline $\begin{array}{l}\text { Appearance } \\
\text { success }\end{array}$ & $\begin{array}{l}\text { Assessment through norm } \\
\text { reference }\end{array}$ & $\begin{array}{lr}\text { Quantity } & \text { understanding, } \\
\text { assessment } & \text { benchmark } \\
\text { reference } & \end{array}$ \\
\hline Assessment & Multiple choice questions & $\begin{array}{l}\text { Portfolio, problem solving, } \\
\text { and performance }\end{array}$ \\
\hline $\begin{array}{l}\text { The use } \\
\text { technology }\end{array}$ & Training and practice & $\begin{array}{l}\text { Communication, access, } \\
\text { collaboration, and } \\
\text { expression }\end{array}$ \\
\hline
\end{tabular}

Relevance with the perspective of learning technology to the demands of globalization demand a change in the reorientation of learning Islamic Religious Education, they are; (1) learning paradigm shift from 'hidden assumption' that knowledge can be transferred intact from the 'brain or mind' teacher from brain or students' thoughts towards learning more'empowering' all aspects of students' abilities. (2) Shifts the paradigm of learning from a teacher-centered (teacher-centered learning) towards studentcentered learning (student-centered learning), self-directed learning (self-learning), and self-understanding (metacognition) because it feels more empowering learning of students in all aspects. (3) shift from learning to 'memorize' concept towards learning 'find' and 'build' (construct) its own concept, which is proven to improve students' ability to think critically, critically, creatively and skillfully solve problems, (4) shifting of learning classical individual toward cooperative learning groups not only to teach thinking skills, but also be able to teach students social skills.

The repositioning of the role of Islamic Religious Education teachers in modern learning, in line with the rapid development of learning technology, then there has been a shift in the view of learning both in the classroom and outside the classroom. In the traditional view in the past (and still exists at the present time), the learning process is seen as: (1) something that is hard and heavy, (2) an attempt to fill a shortage of students, (3) the transfer and receipt of information, (4) individual or solitary process, (5) the activities carried out by describing the subject matter to units of small and isolated, (6) a linear process. 
Dialectics of Educational Technology and Reposition

of Islamic Religious Education: Teachers' Role in Globalization Era

Agus Purwowidodo

In line with the development of learning technology that has been a change of views on Islamic Religious Education learning is learning as a: (1) the natural process, (2) social processes, (3) an active process of passive, (4) a linear process or not linear, (5) the ongoing process of integrative and contextual, (6) the activity is based on a model of strength, skills, interests and culture of students, (7) the activity is assessed based on the fulfillment of tasks, obtaining results, and solving real problems either individually or in groups.

It has changed the role of teacher and students in learning. Islamic Religious Education teacher's role has changed from: (1) as a transmitter of knowledge, the main source of information, subject matter experts, and the source of all answers, that of a facilitator of learning, coach, collaborator, navigator of knowledge and learning partner; (2) of controlling and directing all aspects of learning, become more provide more alternatives and the responsibility to each student in the learning process. Meanwhile, the role of students in Islamic Religious Education has been amended as follows: (1) from passive information receiver to active participants in the learning process, (2) from reveal back knowledge into produces and wide range of knowledge, (3) from learning as individual activity (solitary) into collaborating learning with other students.

Therefore, Islamic Religious Education teachers have basic and vital role in guiding, directing, and educating students in the learning process of Islamic Religious Education primarily as agents of change through a learning process (Davies, 1992: 70), but the Islamic Religious Education teacher's role also will not be replaced by anyone or anything even with advanced technology, Tools and media education, infrastructure, multimedia and technology is simply media or devices that are only used as a teachers' companion (friend-teacher partners) .Perspective of ICT-based learning technologies for teachers of Islamic Religious Education is opportunity and challenge to develop and utilize ICT in learning activities. ICT can be used to improve the quality and productivity of learning.

\section{Conclusion}

From the previous description about the dialectics of learning technology in the globalization era can be concluded that more needs to be done by Islamic Religious Education teacher to address learning problems in the global era, most major Islamic Religious Education teacher should make the development of ICT to become a partner in the designing of innovative learning and integrative accordance with and psychological characteristics of students. Some things that Islamic Religious Education teacher can do associated with the above problems are as follows: (1) The shift in community values due to social changes more quickly this should be offset by an adjustment in the field of learning technologies. It means that technology must be in accordance with the needs of the people who always experience changes so that learning technology is not left with the developments taking place in society; (2) we should always seek their new innovations related to the kinds of learning technologies; (3) Islamic Religious Education teachers should always be able to master existing technology so that the students have confidence in teachers. Technologu mastering can be done by holding a workshop or seminar for teachers related to technological mastery. 


\section{References}

Ade Sanjaya, Problemasi yang dihadapi guru PAI, http://adesanjaya.blogspot.com/2010. Diakses tanggal 25 Juli 2016

AECT Board of Directors. 2012. AECT Standards 2012 version. Tersedia pada url: http://www.aect.org. Diakses pada tanggal 20 Agustus 2016

Aqib, Zainal. (2009). Menjadi Guru Profesional Berstandar Nasional. Bandung :Yrama Widya

Bahtiar, Ali. Kebaikan, Kebenaran, dan Nilai Manfaat Dalam Rumus Dialektika Socrates, (Online), (http://filsafat.kompasiana.com/2013/03/04/kebaikan-kebenaran-nilaimamfaat-dalam-rumus-dialektika-socrates-534176.html\#) diakses 3 agustus 2016

Burrow, S. (1993). National Competency Standards for the Teaching Profession: a hence to define the future of schooling. In Competencies. Canberra: C. Collins, ACE.

Burton, John dan Barbara Locke. "Building Equity Through Learning: Instructional Technology for rural Commmunity Development”, dalam International Journal of Educational Technology, July, 2000, Vol. 2,

Dantes, Nyoman, Perspektif dan Kebijakan Pendidikan Menghadapi Tantangan Global, (online), http://www.undiksha.ac.id/e-learning/staff/images/imginfo/4/7-7.pdf. Diakses pada tanggal 21 Agustus 2016

Davies, B. dan Ellison, L. (1992). School Development Planning. Essex: Longman Group U.K. Ltd.

Earle, R.S., Persichitte, K. A. (2005). Standards For The Accreditation Of School Media Specialist And Educational Technology Specialist Programs. USA: AECT. Ebiefung, Aniekan. Teaching Using the Internet.2009. Chattanooga: University of Tenneessee at Chattanooga. Retreived on July 02 2009, from: cecasun.utc.edu.

Evans, Lionel dan John Leedham. (1985). Aspects of Educational Technology: Educational Technology for Continous Education. London: Kogan Page Ltd.

Gafur, Abdul. "Pendidikan dalam Tantangan Teknologi ICT", dalam Cakrawala Pendidikan: Majalah Ilmiah Kependidikan, Mei 2010 th. XX. No. 2.

Gagne, Robert. (1991). The Conditions of Learning. New York: Holt, Rinehart, and Winston.

Gairola, Chandra Mahesh, Mall Pooja ed., (2004). Information and Communications Technology for Development. New Delhi: Elsevier

Gustafson, Kent. 1991. Survey of Instructional Development Models. (New York: ERIC Clearinghouse on Information Resources Syracuse University

Hartoyo, The Utilization of Information and Communication Technology (ICT) In Language Learning. National Seminar on "ICT and Language Teaching" English Department, Semarang State University. Pada tahun 2008

Heinich, et al. (1996). Instructional Media and Technologies for Learning. New Jersey: Prentice Hall, Inc.

Januszewksi, A., Molenda, M. (2008). Educational Technology: a definition with commentary. USA: Lawrence Erlbaum Assciates

Januszewski, Alan. (2011). Educational Technology: The Development of A Concept. New Jersey: Englewood Publ. 2001

Kenning, M.J. and M.M. Kenning. (1984). An Introduction to Computer Assisted language Teaching. Oxford: Oxford University Press. 
Dialectics of Educational Technology and Reposition

of Islamic Religious Education: Teachers' Role in Globalization Era

Agus Purwowidodo

Labelle, Richard. (2005). ICT formulation and e-strategy development: a comprehensive guidebook. Bangkok: UNDP-APDIP, 2005

Mangal dan Mangal. (2009). Essential of Educational Technology. New Delhi: PHI Learning Private Limited.

Margot, U. (1999). Global Education. Makalah disampaikan pada seminar tentang Bentang Belajar (Learn Scape) tanggal 28 Desember 1999 di Lembaga Penelitian UNY.

Marsh, C.J. (1996). Handbook for Beginning Teachers. Melbourne, Australia: Longman

Miarso, Y. (2004). Menyemai Benih Teknologi Pendidikan. Jakarta: Pustekkom-Predia Media.

Miarso, Yusufhadi. (1987). Landasan Falsafah dan Teori Teknologi Pendidikan. Jakarta: Fakultas Pascasarjana UNJ, 1987.

Miarso, Yusufhadi. (2005). Menyemai Benih Teknologi Pendidikan. Jakarta: Pustekkom Diknas dan Kencana.

Miarso, Yusufhadi. (2008). "Peningkatan Kualitas Guru dalam Persfektif Teknologi Pembelajaran". Makalah, disajikan dalam semiloka yang diselenggarakan oleh UNES pada tahun 2008.

Nyberg, D.A.(1990). Educational Leadership in an Age of Reform. Yew York : Longman.

Robert Reiser dan John Dempsey. (2012). Trends and Issues in Instructional Design and Technology. New Jersey: PearsonEducation Inc.

Rosenberg. Marc J., (2006). Beyond E-Learning - Approaches and Technologies to Enhance Organizational Knowledge, Learning, and Performance. Amerika: . Pteiffer

SETDA. National Educational: $2012 . \quad$ Trend: http://www.setda.org/web/guest/nationaltrenddiakses pada tanggal 12 Juli 2016.

Slamet Suyanto. 1997. Teacher Education Programs At Deakin University:Moving from apprenticeship to School-Based Experience. A short visit report. Melbourne, Australia: CDU.

Suyanto, Slamet. (1997). Teacher Education Programs At Deakin University: Moving from apprenticeship to School-Based Experience. A short visit report. (Melbourne, Australia: CDU.

Wayan, Santyasa, I. (2007). Dimensi-dimensi Teoritis Peningkatan Profesionalisme Guru,(online), http://www.freewebs.com/santyasa/pdf2/.pdf .2007

Young, David "Discourses on Communication Technologies" dalam European Journal of Communication, (2013), London: Sage Publications 
154

Dialectics of Educational Technology and Reposition of Islamic Religious Education: Teachers' Role in Globalization Era Agus Purwowidodo

Ta'dib: Journal of Islamic Education • Volume 21, Number 2, December 2016 P-ISSN: 1410 - 6973; E-ISSN: 2443 - 2512

Available online at http:/ / jurnal.radenfatah.ac.id/index.php/ tadib 